\title{
Neo-mercantilist Capitalism and Post-2008 Cleavages in Economic Decision-making Power in Brazil
}

\section{Kröger, Markus}

2012-05-17

Kröger , M 2012 , ' Neo-mercantilist Capitalism and Post-2008 Cleavages in Economic

Decision-making Power in Brazil ' , Third World Quarterly , vol. 33 , no. 5 , pp. 887-901 . https://doi.org/10.1080/0143

http://hdl.handle.net/10138/154659

https://doi.org/10.1080/01436597.2012.674703

acceptedVersion

Downloaded from Helda, University of Helsinki institutional repository.

This is an electronic reprint of the original article.

This reprint may differ from the original in pagination and typographic detail.

Please cite the original version. 


\title{
Markus Kröger (2012) Neo-mercantilist Capitalism and Post-2008 Cleavages in Economic Decision-making Power in Brazil, Third World Quarterly, 33:5, 887-901, DOI: 10.1080/01436597.2012.674703
}

\author{
Post-print version. For original, and page numbers, please see:
}

http://dx.doi.org/10.1080/01436597.2012.674703

Markus Kröger is in the Department of Political and Economic Studies, Political Science, University of Helsinki, Unioninkatu 37, PO Box 54, 00014 Helsinki, Finland. Email: markus.kroger@ gmail.com.

\begin{abstract}
The 2008 subprime crisis led to a global wave of bailouts and other political-economic measures by governments. These moves were seen as the rise of a new statism. Emerging giants, such as Brazil, introduced new growth policies and reinforced state-crediting of corporations. This article briefly discusses key institutional, structural and ideological lineages and dilemmas in post-2008 statism and capitalism in Brazil. Neo-mercantilist capitalism is visible, for example, in the new 'National Champions' strategy aiming to create export-focused, leading global-sector corporations via mergers orchestrated by key politicians, capitalists and state financial institutions. Changes after a bailout-merger in the paper industry suggest that, after the 2008 financial crisis, in Brazil as elsewhere the use of public funds has had multiple and complex impacts, including the saving of corporations, the concentration of power in those best connected in the political economy, and further exacerbation of class-based inequalities in economic decision making.
\end{abstract}

\section{Introduction}

The recent financial tumults are only one side of a larger set of interacting crises on a global scale: the overaccumulation of capital; global centre-shift; hegemonic transition; and a civilisational crisis encompassing a comprehensive environmental crisis. 1 In the midst of these tumults statism is again being widely embraced. The Brazilian economist Bresser-Pereira believes the 2008 subprime crisis changed global capitalism, and that only middle-income countries engaged in neo-developmentalist strategies will emerge stronger from the turmoil. 2 Already for about a decade Brazil has been building a neo-mercantilist development approach involving 'noninstitutional restrictions on imports using exchange rates, regulation of financial flows, and active promotion of exports'. $\underline{3}$ The neo-mercantilist strategy has benefited Brazil's best interconnected capitalists and politicians, and will foreseeably continue to do so as Brazilian clout advances in the international political economy. However, the industry restructuring cases discussed in this article suggest that the new mercantilist and developmentalist strategies adopted also augment class cleavages and inequality in economic decision making, by trying to push alternative views that do not fit in the neo-mercantilist consensus into the margins.

Statist steering of the economy is a more legitimate alternative after the subprime crisis, which was built by massive increases in fictitious capital, financial globalisation and the hegemony of neoliberal ideology beginning in the 1980s. 4 In one sense this is a return to the stronger government interventions experienced between 1950 and 1970. In fact, many of the new statist policies rely for their execution on institutions established during that era. Yet, as can be expected, many things are new in new statism, thanks, for example, 
to the legacy of 1990s privatisations, other neoliberal measures, strategy differences and new decision makers. In this article the class cleavage dilemmas of neo-mercantilist capitalism are scrutinised through an analysis of state-led industry financial restructuring, particularly the creation of the paper pulp giant Fibria with National Development Bank (bndes) funding in the aftermath of 2008.

Brazilian government strategy, using a comprehensive set of policy tools and funds to fashion an active state promoting global market competitiveness alongside social inclusion, $\underline{5}$ is a variety of new statism. The Brazilian state and corporations are likely to fare well using the statist strategy and the transformations in global capitalism they are increasingly creating rather than dependently receiving. Yet some sectors of Brazilian society potentially stand to lose in the country's neo-mercantilist capitalism, which will reinforce problematic institutional and structural arrangements and ideologies long identified by both practitioners and scholars of Brazilian politics as key obstacles to building a more democratic, equal and sustainable society and economy. Neo-mercantilism seems to be exacerbating rather than resolving the power concentration associated with state corporatism and structural inequality identified as seminal characteristics of the country's political economic system. $\underline{6}$ The division of power between state, industry and workers is played down in global cloutseeking neo-mercantilism. Attention is given to creating jobs, raising minimum salaries and offering social welfare benefits and programmes, but structural economic cleavages, such as access to capital goods, to the means of production (including land) and to decision making, are becoming steeper: equalising class relations, in the Marxists sense, is not the central focus, instead the focus is on increasing the clout of the most powerful national economic and political groups in the international political economy (ipe). The reasons for this are to be found in historical mechanisms still in vigour and government policies maintaining the decision-making cleavage in the Brazilian variety of capitalism.

Varieties of state roles in capitalism, for example in industrialisation and development, have been extensively studied using institutional analysis. 7 Statist political economies, particularly in the Third World, attempting to rise to the capitalist club via growth-inducing public industrial policy, have been called developmental states. $\underline{8}$ New statism in the emerging markets has largely adopted a neo-developmentalist agenda. 9 According to Boschi, Latin America's neo-developmentalism focuses more attention on national dynamics than on 20th century Cepalian-structuralist developmentalism; the objective of this model-in-formation is to construct a space for coordinating the public and private spheres, thus increasing national wealth and social well-being. 10 In Brazil developmentalism started a new golden age around 2005 with new developmental projects such as the Project of Growth Acceleration (pac). 11 Neo-developmentalism can be seen as a tool within the neomercantilist strategy of increasing national power in the ipe by statism. Developmentalist manoeuvres reorder the territorial, socio-political and economic fabric through large-scale infrastructure, energy and export-growth augmenting projects and industrial restructurings, so that the larger goals of neo-mercantilism are secured. The main mercantilist goal is to increase state clout in the ipe, which allows greater security and expansion, and control over territories; economic gains are the means to achieve these main goals.

Neo-developmentalism is used by neo-mercantilists as it integrates a national system of control and export-led accumulation of capital. Large-scale developmental projects enclose previously 'unused' (by big capital) territories and/or areas the mercantilists fear losing to competing economic actors, such as foreign states, transnational corporations and international non-governmental organisations, whose land acquisition in Brazil has been severely limited by new laws during the past decade to secure territories (often inhabited by poor 
rural populations) for national big private and state capital. Brazilian elites have long feared the loss of the Amazon, in particular, to foreigners and since the 1960s their central geopolitical tool of securing the area for (Southern) Brazilians has been developmentalism. 12 Elites are also increasingly active in extending their clout across the ipe, particularly in the global South, also a sign of neo-mercantilist agenda.

Neo-mercantilist capitalism was strongly fortified after 2008, for example by a policy creating 'National Champions'. In 2008-10, according to The Economist, 13 the government ramped up resources in the bndes by at least $\mathrm{R} \$ 210$ billion ( $\$ 120$ billion), 'for infrastructure projects and a host of other ventures less obviously deserving of state support'. bndes has been the central institution executing developmentalist policies in Brazil since the 1950s. 14 In early 2009 the government poured $\mathrm{R} \$ 100$ billion ( $\$ 56$ billion) from the Federal Reserve into bndes, in exchange for equity stakes, for bailing out large corporations in 'key sectors' that had speculated and lost on the derivative markets, for example. 15 The largest paper companies, Aracruz and Votorantim, important export-revenue gainers, were bailed out.

Bailouts of big capitalists operating recklessly in the markets and social peripheries have roused the concern of some economists on whether tax money is being used in the best possible way: 'According to ipea, a government-linked research outfit, the bndes's subsidised interest rates cost taxpayers up to 21 billion reais [\$11.8 billion] a year'.16 Economists and political scientists in Brazil who believe in developmentalism have mostly been thrilled about the return of the state, although they have not yet tackled the details of how and where the state is increasing its role in the economy. 17 Political ecologists, among others outside the neomercantilist consensus (and gains), have been much more critical when assessing the consequences of neodevelopmentalism. Despite, or perhaps precisely because of, the potential for China-like gdp growth, neodevelopmentalist projects are placing the livelihoods of many displaced rural populations in danger. For environmental anthropologist Zhouri, Lula da Silva's presidency (2003-10), did little to shift the negative socioenvironmental consequences of the military governments' (1964-84) developmentalist agenda. A principal argument Zhouri uses to back up this claim is the launch of the pac programme in 2007, which consists of a set of projects aimed at accelerating economic growth, particularly through infrastructure building and resource exploitation in the Amazon, with a total investment of $\mathrm{R} \$ 503.9$ billion ( $\$ 284$ billion). 18 In comparison to developmentalists and political ecologists, business administration scholars, such as Lazzarini, $\underline{19}$ have offered more nuanced analyses of the new state-society relations and their political-economic consequences in Brazil, based on more detailed assessment of the positioning of key politicians and capitalists in Brazil's 'capitalism of ties'. I will use these and other institutionalist theories in discussing power and class relations in the decision making of neo-mercantilist capitalism.

\section{Historical institutionalism and (new) Brazilian capitalism}

Deriving from the historical materialism of $\mathrm{M}$ arx and the comparative institutional history of Weber, 20 historical institutionalism sees the set of power relations in a given political system as a key to explaining changes in the political economy. The focus is on the study of separate but interlinked institutions and actors, especially those linked to the state, which has a strong role in creating and moulding markets. 21 The approach can be used for assessing the mechanisms maintaining class cleavages within economic decision making. Key mechanisms explaining decision-making inequalities in neo-mercantilist statism in Brazil include state corporatism, ideological developmentalism, and unequal distribution of wealth and access to resources. 


\section{Lasting state corporatism}

Even though some important changes have taken place, the state still has corporatist ties with both labour unions and corporations, and this state corporatism (tending to favour corporations) continues to influence the Brazilian economy, politics and society. 22 President Getulio Vargas's authoritarian regime implanted state corporatism in Brazilian society in the 1930s. In state corporatism, following the strategy outlined by Oliveira Viana, the state would actively promote links between its own structures and the leaders of both companies and labour.23 This change in the governmental strategy of ordering power relations between economic actors had long-lasting impacts. For example, since 1930, when the entry of new entrepreneurs and owners into companies was made more difficult, traditional family enterprises with capital have expanded in an environment of limited competition and a strong government distributing most of the available credit. 24 State corporatist structures have also meant that trade unions and industries do not organise horizontally over industry- or profession-specific lines, but hierarchically. 25 Not surprisingly capitalism in Brazil has been called hierarchical, $\underline{26}$ despite attempts to dismantle the legacy and power of state corporatist institutions, and transform them into neo-corporatism, in which civil society associations and autonomous workers would gain deliberative power. 27

Although councils and other participatory democracy institutions have also been developed, the institutional arrangements initiated in 1930 are largely still in place. For example, the state corporatist legacy negatively influenced the long-term and hard-fought, though ultimately failed, attempt to create an autonomous central trade union in 2010.28 On 11 M ay 2011 President Roussef installed a new state corporatist institution, the Chamber of Management Policies, Performance and Competitiveness, formed by four ministries and four largescale entrepreneurs.29 The goal in creating the institution, according to Roussef, is to maintain good relations with the private sector, without conflicts of interest, and to optimise the performance of the executive power in serving society, reducing costs, and rationalising processes and policies. According to the director of the Chamber, Jorge Gerdau, owner of a large globalised Brazilian steel company, the priority is to guarantee that the country keeps on growing and controls inflation. Yet this institutional opening also gave Brazil's biggest capitalists one more channel of direct access to state bureaucracies. Thus there are clear signs of state corporatism in the country.

\section{Who is in control? And did neoliberalism really diminish the role of the state?}

In the post-2008 setting who is in control: government or capital? A study on Brazil's 'capitalism of ties' argues that, thanks to the way they were introduced under Fernando Henrique Cardoso's presidency (1995-2002), neoliberal reforms such as privatisations created a context of fostering an interdependent association between foreign and national capital, along the lines outlined by Cardoso and Faletto in the 1960s. 30 This type of privatisation ended up strengthening the power of state institutions in economic decision making, which is why Lazzarini rebuts the commonly held view that neoliberalism has diminished state coordination of the economy. In Lazzarini's words, 'Fernando Henrique, far from "forgetting what he wrote", in reality helped to sow the capitalism of ties in Brazil. And created bases for its reinforcement in the subsequent government (Lula)'. 31 Similarly, Gomes states that neoliberalism actually fortified the state corporatist system in Brazil. 32 Abu-El Haj argues that intentional government policies during Cardoso's time led to an inversion of the hierarchy within the ruling classes in favour of local capital; at the end of Cardoso's tenure his inner circle of developmentalist 
economists, including Bresser-Pereira, pushed for the adoption of neo-mercantilism. According to Abu-El-Haj, after Cardoso, a neo-mercantilist consensus was adopted among the most important politicians, industry groups, banks and economic think-tanks: this has led to 'underdeveloped capitalism and inequality' and ended the relatively autonomous policies of Cardoso 'that advanced the interests of the entire bourgeoisie without degenerating into clientelistic support for particular firms'. 33 These institutional arrangements, even after neoliberal privatisation reforms (both advanced to varying degrees by the Cardoso and Lula governments) give big local capital preferential institutional access to the state, unifying the objectives of government and big capital so that it is hard to distinguish between them. This alliance also supports developmentalist and neomercantilist interests and delimits the institutional access of contentious actors, such as trade unions criticising investment policies.

A political-economic-social class elite still exists in Brazil and keeps on accumulating power. Such elites hold most of the high salary earning positions, which offer their holders 'a privileged position from which to influence in the legislative and legal process, the administration of the public machine, the hiring of large quantities of workforce or even in the formation of public opinion'. 34 Eakin writes that: 'In the 1990s, 287 of Brazil's 300 largest corporations were controlled by families...the continuity of elite families and their networks is impressive'. 35 After waves of corporate mergers in the past decade, the figure is even more concentrated. $\underline{36}$ One percent of the population controls more wealth than the poorest 50 per cent. 37 Five thousand Brazilian families, 0.001 per cent of the population, control 40 per cent of the country's gdp. $\underline{38}$

For M edeiros, as 'wealth and political power are associated', economic growth under this institutional trajectory cannot resolve the dilemma of under-development and corresponding inequality. 39 By contrast, Bresser-Pereira argues that developmentalism will resolve these problems. 40 For Lazzarini, too, the institutional and structural characteristics of the Brazilian 'capitalism of ties' are not wholly negative, but also allow synergy benefits by pooling resources and limiting investment risks. 41 Even via modest changes in the trajectory, much has also improved in Brazilian society in the past decade. 42 For example, during Lula's terms in office, incomes rose dramatically for the lower classes, mostly through the 60 per cent rise in minimum wages and less so because of the much-lauded Bolsa Familia programme. 43 Brazil's neo-mercantilist capitalism has led to increases in the incomes of lower classes, because it has been applied to schemes eradicating extreme poverty and offering more job opportunities for the lower and new middle classes, as well as reinforcing class cleavages in economic decision making by corporate, national elite capital favoured for example by bailout-schemes.

\section{Power relations in neo-mercantilism: workers, 'National Champions' and finance capital}

In 2008 the largest Brazilian paper pulp producer and exporter, Aracruz Celulose, practically defaulted as a result of massive derivative speculation losses totalling US $\$ 2.13$ billion, $\underline{44}$ and a standing debt of $\$ 7$ billion. $\underline{45}$ Votorantim Celulose e Papel (vcp), Brazil's second largest pulp producer, also suffered excessive losses after betting on a high real to dollar exchange rate. As in many other settings of the 2008 financial crisis, the state intervened in a rescue operation. Thanks to a loan of $\$ 1.35$ billion liberated by bndespar, the state made it possible for vcp (which also almost defaulted) to buy Aracruz, merging the two heavily weakened pulp producers into Fibria. The merger followed the government's 'National Champion' creation strategy, aiming to turn Brazilian corporations into leading players in their sectors, within the global top $10 . \underline{46}$ In terms of size the 
strategy worked. Fibria immediately became the world's largest bleached pulp producer with over 797000 hectares (and counting) of its own tree plantations across Brazil. 47 Backed by this neo-mercantilism, the country's pulp production and exports are booming, with a new 1.5 million ton mill forecast to enter into operation every year until at least 2016. $\underline{48}$

The creation of Fibria was steered by bndes and the pulp capital-owning elite family clans, principally Ermírio de Moraes of Votorantim, Brazil's largest multi-industry conglomerate of private capital, with near-monopolies in several sectors. M oraes is among the 10 most influential 'counsellors of interconnection', or 'owners of power' in Brazil's 'capitalism of ties'. 49 According to Lazzarini, these central corporate board members are the most powerful in politics and the economy, and characterise Brazil's variety of capitalism by their intermediation of market and government goals.

Poor people's social movements, workers, and other lower class actors are largely ignored by this setting. Company workers have experienced the pressure of neo-mercantilism because of the 'National Champions' policy. After the fusion of Votorantim and Aracruz in 2009, with Moraes in a commanding position, Fibria let go 200 Aracruz workers and closed the Aracruz workers' pension fund, the Fundação Aracruz de Seguridade Social. According to Sinticel-es, the Aracruz trade union in Espírito Santo and its allies, Fibria ordered the workers to join another fund, Funsejem, Fundação Senador J osé Ermírio de M oraes, named after M oraes himself, at the same time severely cutting workers' benefits, rights and remunerations which had already been promised. $\underline{50}$

The cutting of workers' rights is also an example of the dynamics present throughout the neoliberal period, including during the crisis which started in 2008, where the discourse of 'it is necessary to cut costs because of financial losses' is used to augment profits, skew power relations, and restructure the rules of and access to political games determining economic policy. Fibria's Aracruz operations made a profit of $\$ 673$ million in 2008, and $\$ 314$ million in the first quarter of 2009, 51 so there was no real need to cut workers' benefits. Even though Aracruz did end 2008 with a liquid deficit of $\$ 2.35$ billion as a result of the derivative losses, $\underline{22}$ the financial situation was balanced by the renegotiation of debt obligations with banks, $\underline{53}$ the merger sale to Votorantim, and bndes credit. Furthermore, Fibria's financial situation was strongly balanced when it sold the former Aracruz pulp and paper plant at Guiaba in Rio Grande do Sul, with 212000 hectares of eucalyptus plantations, for $\$ 1.43$ million to a Chilean pulp company. 54 However, Fibria continued to demand deeper cuts in existing benefits and rights, and since Sinticel did not approve the cuts in November 2009, in March 2010 the company forced even more severe cuts than it had proposed earlier, without any remuneration, and even managed to get a judicial decree to close the trade union's bank accounts. $\underline{5}$ Such moves allow greater corporate profitability and globalisation.

The closing and renaming of a workers' pension fund by a patron is an illustrative example of the vitality of state corporatism that paternalises workers and punishes renegades of developmentalist orthodoxy. Sinticel is a member of the highly critical Network Against the Green Desert resisting eucalyptus monocultures, which is quite interesting considering that the workers were critical of the industrial tree plantation-based large-scale pulp investment style, and tried to influence this through non-official channels, since official channels were unavailable.

This is one of the dark sides of the 'National Champions' policy: cutting costs, workers' rights and decisionmaking power in all possible ways at home, so thatthe new companies' owners can dominate the global 
capitalist setting, and start to distribute their form of minimum-cost capitalism to other countries where they globalise as well. In another example, Vale, Brazil's leading miningcompany, attempted to significantly worsen the workers' contracts in a Canadian steel company it acquired in 2010: in an interesting reversal of traditional South-North dynamics, the developing country multinational was worsening conditions in the North, not vice versa. A one-year strike by the M etal Workers' Union of Canada ensued, and a transnational network of thoseaffected by Vale was built, creating such movements as Justice on the Rails (or Tracks) from Brazil's iron exporting rail corridors. $\underline{56}$ Vale's attempt failed, and a new transnational network attempting to steer Vale's behaviour, and thus the 'National Champions' policy, was created.

The Fibria and Vale dynamics reveal much about the lot of workers under neo-mercantilism. Brazilian corporations aiming to globalise on a basis of cutting costs appear to have very limited goodwill or solidarity to negotiate with organised labour or other contentious actors to create coalitions that could democratically shape investment policies. In principle, workers have a democratic right to influence bdes financing. Brazil's labour legislation, dating from the 1930s, demands that companies place 15 per cent of salaries into workers' pension and insurance funds (ftas), created by companies, not workers; by law, 40 per cent of the fats funds go directly to bndes operations. 57 The cutting of workers' rights in bndes-financed mergers underlines the outsider-status of workers in Brazil's 'capitalism of ties'.

\section{Institutions of neo-mercantilism: bndes in Brazil's 'capitalism of ties'}

The process by which Fibria was created presents an opportunity to study the re-emergence of neomercantilist capitalism in the new configuration of the post-2008 multipolar world, where developmentalist nations have become more influential among the variety of capitalist countries. In particular, it is useful to focus on the ways bndes was used in the merger, as it is the central institution in the new 'National Champions' policy of the Brazilian government.

The 1990s neoliberal and decentralising reforms of the Brazilian state left the bndes structure mostly intact, which preserved its crucial importance, strategic role and funding policies set during the strongest developmentalist era of 1940-70.58 The bank's role in the economy, offering very low interest rates and credit mostly to big national corporations, helps us assess the type of statism active in Brazil's government-business relations. bndes is the fundamental instrument helping Brazilian companies to buy capital goods, and is virtually the sole source of funding allocated to the acquisition of machinery and equipment produced in Brazil. 59 In addition to the fats, bndes also receives funding from other sources, eg since 2008 via direct reimbursements from the Federal Reserve. The functionally autonomous bndes, controlling about 20 per cent of the total credit in the Brazilian economy, $\underline{60}$ distributes the ample credits coming from fats and the Federal Reserve to privileged corporations. Not surprisingly, the industrialist Eike Batista, Brazil's richest man and the eighth richest in the world, with a fortune of $\$ 27$ billion and aiming for $\$ 100$ billion, 61 thinks bndes is 'the best bank in the world'.62 Batista's and the government's goals are closely intertwined and rely for their success on neo-mercantilism. Though closely connected, the aims of the government and big capital differ tremendously in the last instance: governments seeks security in the ipe (not unconnected to neo-mercantilist aims, Brazil has started a vigorous diplomatic campaigning to attain a seat in the United Nations' Security Council), and big national capitalists seek (globally recognised) wealth for its own sake, that is, for the sake of class distinction. These are the dreams of today's leading politicians and capitalists. 
Besides bndes the government has embedded in the private sector the largest pension funds in the emerging countries ( $\$ 306$ billion, 18 per cent of gdp); these pension funds are administrated by the governing Workers' Party (pt) trade unionist 'aristocracy', with a large portion going to finance bndes operations, $\underline{63}$ particularly the 'National Champions' policy. The majority of these pension funds are invested in government bonds, although a significant percentage is also in stocks: 64 public pension funds are prominent in all 'National Champion' companies. When companies such as Aracruz suffered dramatic losses in the tumults of their 2008 financial speculation that were greater in value than the pulp producing business, the value of Brazilian public pension funds and banks which had not engaged in pulp company-type dollar derivative speculation did not suffer significant losses. This gave the pt government a good opportunity to influence the private sector, part of which was desperately in need of capital to survive after its failed incursions into global financial capitalism.

Votorantim and Aracruz owners and directors were already planning a merger before 2008. $\underline{65}$ Their derivative losses made the entry of state capital necessary, as all other funding sources were closed. This gave bndes significant ownership in the new pulp company Fibria. The government could potentially use its steering power to change corporate governance or investment style, although in practice it has mostly not meddled in the investment styles of corporations as it shares their developmentalist views and neo-mercantilist aspirations towards the ipe. Yet, if key corporations do not follow the broad neo-developmentalist investment agenda, the government has increasingly started to steer decision making for example by forcing directors pursuing different investment strategies to step down. In a 2010 case the government prompted Vale to start building steel mills in the Eastern Amazon (M arabá) and Fortaleza, instead of submitting to the wishes of professional managers and international owners to use profits and credit to transnationalise. In this intervention Lula used the political-economic clout of his friend Eike Batista, $\underline{66}$ gaining the sympathies of those embracing the idea of national industrialisation via large-scale resource-based extraction and semi-processing. Besides aiding the neo-mercantilist agenda, in general favouring his business empire and the national project, Batista gained a stronger foothold in the world's largest iron-ore company, Vale.

\section{Discussion: financialisation of the new, corporate internationalisation-oriented statism}

Brazil's new statism has the qualities of strong developmentalism and state corporatism, but with the new character of channelling most of the capital harnessed in the country to promote the international competitiveness and even globalisation of the largest Brazilian corporations. bndes, pension funds, the government and central connecting capitalists have had operations similar to the creation of Fibria in other sectors as well, creating the top three global companies in their industries, and becoming their main shareholders: for example, mining (Vale), petroleum (Petrobras), aviation (Embraer), and meat processing (jbsFriboi and Pilgrim's Pride into Brasil Foods). 67 As a result of these financial operations, bndes is the biggest stock-holder in the largest Brazilian corporations.68 The pension funds of Brazilian corporations also have considerable ownership holdings. Cross-ownership implies national and concentrated control over decision making. For example, Vale is controlled by the holding company Valepar, of whose voting power 60 per cent is shared by the pension funds of the state-owned Bank of Brazil (Previ), the half-state-owned Petrobras (Petros), and bndesPar.69 Thereafter, significant economic decision-making power should in theory lie with the workers in these companies. 
A significant market mechanism and tendency concentrating decision-making power is sectoral investing by 'National Champions' across government-denominated key sectors. These key export sectors receive the most bndes funds, which largely explains the cross-sectoral investing of big capitalists. For example, jbs-Friboi, the world's largest meat-packer, also mostly owned by the Batista family, is building a 1.5 million ton pulp mill called Eldorado in Três Lagoas, M ato Grosso do Sul, which already has massive pulp ventures involving Fibria: in a few years the region will end up with over half a million hectares of eucalyptus and the capacity to produce five million tons of pulp. 70 This investing in pulp by a meat-packing firm whose stocks are mostly owned by the country's richest family (Batista), by pension funds and the state shows how resource extraction is treated by financial logic, where it hardly matters if an entrepreneur is technically skilled in an industry. The overriding financial logic - visible in both liberal and mercantilist systems across the globe-is particularly ingrained in Brazil's new neo-mercantilism (in comparison to the classic import substitution industrialisation neomercantilism for example, which sought to create national industrial production): the main aim is to gain international security by maximising foreign currency reserves. This is important in contemporary global capitalism, where sovereign states have become hostages of a banking system that is too big to default, has to be bailed out by taxpayer money poured into 'stability funds', and continues to invest recklessly and unstably as fundamental structural changes are not made. Brazilian pension fund decision makers aiming to maximise returns have surely seen cost calculations where pulp investments pay themselves back in five years and thereafter deliver over $\$ 250$ million profit per year, and have bought a pulp investment package, looking primarily at capacity to create reserve capital, and ignoring job creation, environmental or industrialisation concerns. 71

The shares of these currently national, soon potentially to be global, Champions are mostly controlled, one way or another, by a handful of the richest and best connected capitalists and politicians. This group also includes, with less power, privileged directors and workers in big corporations, who were also the ones to benefit the most from the 1990s privatisations through their right to buy or ability to take over (sometimes illegally) shares almost for free. In this setting, the majority does not gain directly or have a say in the most important changes in the economic structure.

Within the elite, the power of the most powerful is also increasing. Paper industry experts, such as Scheibe, foresee that the 2010s will see the end of traditional family entrepreneurs in the paper industry (Klabins, Feffers of Suzano, Emirio de M oraes of Votorantim/Fibria), shattering their complex politician/diplomat/ entrepreneur roles, and giving way to impersonal management by mbas specialising in finance, steered by the big financial capital that profits and gain most power with neo-mercantilism. The Lorentzen family of Norway, a pioneer investor in the Brazilian pulp industry, was bought out from Aracruz in 2007 by better-connected national capitalists. 72 Looking back, the time of selling could not have been better for the Lorentzens, considering Aracruz's 2008 derivative losses. The entrance of Batista into the industry, with no experience in pulp, also signals that the financialised capitalism of technical managers steered by the biggest capital is taking over engineer-owned industrial capitalism as the main tool for creating class distinctions and limiting the range of decision-making possibilities.

\section{Conclusion}


This article has analysed Brazil's post-2008 capitalism and power relations in the context of the rise of neomercantilism, the creation of 'National Champions', and industry-National Development Bank partnerships. Neomercantilism has had multiple impacts on Brazilian capitalism and industrial policy. The macroeconomy is stable and growing; many jobs have been created and formalised; incomes have risen; and the domestic market is growing. 73 Remuneration for the lower classes mostly outside the spoils of neo-mercantilism is to be expected from the misery-eradicating and other progressive policies launched by President Dilma Roussef. Some democratising changes have taken place in institutional politics, for example through the meritocratisation of justice, public prosecution, and some environmental institutions, deliberative democracy between the Land Agency Incra and the Brazilian Landless Movement (mst), and a stronger execution of anticorruption and criminal investigation procedures.74 However, the decision-making power of the lower classes has increased mostly only in institutions and mechanisms with limited or no access to the most important economic funds. bndes decision making and projects continue mostly to be directed towards short-sighted corporate profit-maximisation following the current financial logic, and alternative voices and projects from below are not incorporated into the decision-making process, even though they might benefit from some minor investments. This is largely a result of the historical legacies of state corporatism and developmentalism, along with the bank's institutional autonomy, which offers privileged access to neo-mercantilist politicians and corporate agents and shuns ideologically heterodox viewpoints.

These cases of industry restructuring suggest that the creation of global industry leaders, such as Fibria in the pulp producing sector and Vale in mining, has not come without a price. The structural politics continue to be skewed in favour of the elite, in a process where capital territorialises ever more peripheral regions of the country. The National Champion strategy seems to be concentrating industrial capital in the hands of national elites and the state. The world system, after a period of neoliberal globalisation extending the power of multinational Western companies, is seeing a partial de-globalisation of finance. 75 National and state-steering does not necessarily mean greater democracy in the global South, however. For the majority of the working class, if national control of markets and credit is oligarchic, neo-mercantilism can be worse than other varieties of capitalism. The role of the bndes is a good example of this.

According to Lazzarini, in Brazil's current 'capitalism of ties', the 'owners of power' are the centrally entwined connectors between private and public actors. $\underline{76}$ Institutional channels of deliberative democracy already exist, Brazil being a global innovator in these. What is needed, however, is to bridge the class cleavage through structural transformations that reposition agents and introduce new key connectors with heterodox ideas. Contentious agents themselves (not their party-political representatives, who overtly favour developmentalism), such as critical trade unions, should be given formal decision-making and strategy-creation power in the most important economic institutions, such as the bndes, particularly in relation to projects which influence them and which are financed by their pension funds. Even in purely economic/liberal terms the 'National Champions' strategy could be criticised for leading to monopoly capitalism and restricting innovation, competition and the potential for real change. 77 The opportunity and quality costs of concentrating capital in order to create global giants, while not financing many small and new projects and companies, are enormous.

\section{Notes on contributor}


Markus Kröger is an Academy of Finland Postdoctoral Researcher in the Department of Political and Economic Studies, University of Helsinki. His research focuses on the politics of corporate resource exploitation, social movement resistance, and industrial forestry and mining-based conflicts in South America and Asia, particularly in Brazil and India and the paper and pulp industry. He has recently been a visiting scholar in the Department of Sociology, UC Berkeley, and the Department of Forest Products, Swedish University of Agricultural Sciences. This research was written while the author had funding for research projects from the Kone Foundation and the Academy of Finland.

\section{Notes}

1 B Gills, 'Going South: capitalist crisis, systemic crisis, civilisational crisis', Third W orld Quarterly, 31(2), 2010, pp 169-184.

2 L Bresser-Pereira, 'The global financial crisis and a new capitalism?', Journal of Post Keynesian Economics, 32(4), 2010, pp 499-534.

3 J Abu-El Haj, 'From interdependence to neo-mercantilism: Brazilian capitalism in the age of globalization', Latin American Perspectives, 34(5), 2007, p 109.

4 Bresser-Pereira, 'The global financial crisis and a new capitalism?'.

5 G Arbix \& S M artin, 'Beyond developmentalism and market fundamentalism in Brazil: inclusionary state activism without statism', paper presented at a workshop on 'States, Development, and Global Governance', University of Wisconsin-Madison, 2010.

6 See D Collier \& R Collier, 'Who does what, to whom, and how: toward a comparative analysis ofLatin American corporatism', in J Malloy (ed), Authoritarianism and Corporatism in Latin America,Pittsburgh, PA: University of Pittsburgh Press, 1977; E Diniz, Voto e Máquina Política: Patronagem e Clientelismo no Rio de Janeiro, Rio de Janeiro: Paz e Terra, 1982; T Power \& M Doctor, 'Another century of corporatism? Continuity and change in Brazil's corporatist structures', in H Wiarda (ed), Authoritarianism and Corporatism in Latin America-Revisited, Gainesville, FL: University Press of Florida, 2004; and M Pochmann, A Guerra, R Amorim \& R Silva (eds), Atlas da Nova Estratificação Social no Brasil: Classe M édia, Desenvolvimento e Crise, São Paulo: Cortez Editora, 2006.

7 J Zysman, 'How institutions create historically rooted trajectories of growth', Industrial and Corporate Change, 3, 1994, pp 243-283; P Evans, Embedded Autonomy: States \& Industrial Transformation, Princeton, NJ: Princeton University Press, 1995; and P Hall \& R Taylor, 'Political science and the three new institutionalisms', Political Studies, XLIV, 1996, pp 936-957.

8 P Evans, Dependent Development: The Alliance of M ultinational, State and Local Capital in Brazil, Princeton, NJ: Princeton University Press, 1979; Evans, 'Constructing the 21st century developmental state: potentialities and pitfalls', in 0 Edigheji (ed), Constructing a Democratic Developmental State in South Africa: Potentials and Challenges, Capetown: hsrc Press, 2010, pp 37-58; and R Almeida, 'Entrando no clube: 0 bndes e a inserção Brasileira no capitalismo internacional', in R Boschi (ed), Variedades de capitalismo, política e desenvolvimento na América Latina, Belo Horizonte: Editora ufmg, 2011, pp 164-193. 
9 Bresser-Pereira, 'The global financial crisis and a new capitalism?'.

10 CEPAL, The United Nations Economic Commission for Latin America, promulgated a particular structuralist developmentalism. CEPAL-type structuralism emphasized centre-periphery relations to explain underdevelopment. The focus was on regulating international trade policy; this developmentalism flourished from the 1940s to the 1960s.

11 R Boschi, 'Instituiç[otilde]es, trajetórias e desenvolvimento', in Boschi, Variedades de capitalismo, política e desenvolvimento na América Latina, p 13.

12 A Zhouri, "'Adverse forces" in the Brazilian Amazon: developmentalism versus environmentalism and indigenous rights', Journal of Environment \& Development, 19(3), 2010, pp 252-273.

13 'Brazil's new president: coming down to earth', The Economist, 28 December 2010.

14 E Diniz \& R Boschi, Empresários, Interesses e M ercado-Dilemas do Desenvolvimento no Brasil, Belo Horizonte: Editora ufmg, 2004.

$15 \mathrm{G}$ Parra-Bernal, 'Brazil beefs up bndes budget by 100 billion reais', 2009, at http://market memorandum. blogspot.com/2009/01/brazil-beefs-up-bndes-budget-by-100.html.

16 'Brazil's new president'.

17 See, for example, Bresser-Pereira, 'The global financial crisis and a new capitalism?'; and R Boschi, 'Instituiç̧otilde]es, trajetórias e desenvolvimento', pp 7-31.

18 Zhouri, '"Adverse forces" in the Brazilian Amazon'.

19 S Lazzarini, Capitalismo de laços: Os donos de Brasil e suas conex[otilde]es, Rio de Janeiro: Elsevier, 2011.

20 J Campbell, 'Problems of institutional analysis', in Campbell, Institutional Change and Globalization, Princeton, NJ: Princeton University Press, 2004.

21 P Evans, Embedded Autonomy.

22 E Diniz \& R Boschi, Empresários, Interesses e M ercado; A Boito, 'Estado e burguesia no capitalismo neoliberal', Revista de Sociologia e Política, 28, 2007, pp 57-73; and W Mancuso, 'O empresariado como ator político no Brasil: balanço da literatura e agenda de pesquisa', Revista de Sociologia e Política, 28, 2007, pp 131-146.

230 Viana, Populaç[otilde]es M eridionais do Brasil: História-Organizacão-Psychologia, São Paulo: M onteiro Lobato \& Cia Editores, 1922; and J Carvalho, 'M andonismo, coronelismo, clientelismo: uma discussão conteitual', Dados, 40, 1997, pp 229-250.

24 Lazzarini, Capitalismo de laços, p 119.

25 T Power \& M Doctor, 'Another century of corporatism?'. 
26 B Schneider, 'A comparative political economy of diversified business groups, or how states organize big business', Review of International Political Economy, 16(2), 2009, pp 178-201.

27 M Doctor, 'Lula's development council: neo-corporatism and policy reform in Brazil', Latin American Perspectives, 34, 2007, pp 131-148.

28 J Berterretche, 'Brasil petista: social-liberalismo com vocação "desenvolvimentista"', Desacatobrasil, 15 October 2010, at http:// desacato.info/2010/10/brasil-petista-social-liberalismo-con-vocacion\%E2\%80\%9Cdesarrollista\%E2\%80\%9D/.

290 Globo (Rio de Janeiro), 12 May 2011, p 11.

30 Lazzarini, Capitalismo de laços, p 119; and F Cardoso \& E Faletto, Dependency and Development in Latin America, Berkeley, CA: University of California Press, 1979.

31 Lazzarini, Capitalismo de laços, p 14.

32 E Gomes, 'Reforming with the reforms: liberalization, democratization and corporatist institutions in Brazil', paper presented to the International Studies Association Annual M eeting, M ontreal, 2004.

33 Abu-El Haj, 'From interdependence to neo-mercantilism', p 110.

34 M M edeiros, 0 que faz os Ricos ricos: 0 outro lado da desigualdade brasileira, São Paulo: Editora Hucitec, 2005, p 251.

35 M Eakin, Tropical Capitalism: The Industrialization of Belo Horizonte, Brazil, New York: Palgrave, 2001, pp 173-174.

36 Berterretche, 'Brasil petista'.

37 Medeiros, 0 que faz os Ricos ricos.

38 Pochmann et al, Atlas da Nova Estratificação Social no Brasil.

39 M M edeiros, 0 que faz os Ricos ricos, p 251.

40 Bresser-Pereira, 'The global financial crisis and a new capitalism?'.

41 Lazzarini, Capitalismo de laços, p 111.

42 For a review of the positive changes, see C Santana, 'Conjuntura crítica, legados institucionais e comunidades epistêmicas: limites e possibilidades de uma agenda de desenvolvimento no Brasil', in Boschi, Variedades de capitalismo, política e desenvolvimento na América Latina, pp 121-163.

43 'Brazil's north-east: catching up in a hurry', The Economist, 19 M ay 2011.

44 Aracruz Celulose, 'M aterial information release', 19 January 2009. 
$45 \mathrm{~V}$ Bacchetta, 'La industria de la celulosa y la crisis mundial: desensillando hasta que aclare', 17 October 2009, at www.ecoportal.net.

46 'Demiss[otilde]es nas papeleiras', Correio Braziliense (Brasilia), 4 M ay 2009.

47 Fibria, 'Institutional-about us', 2011, at http://www.fibria.com.br/web/en/institucional/quem.htm.

48 bndes, 'bndes aprova financiamento de $\mathrm{R} \$ 2,7$ bilh[otilde]es para a Eldorado', 6 June 2011, at http://www.bndes.gov.br/SiteBNDES/bndes/bndes_pt/Institucional/Sala de Imprensa/Noticias/2011/indus tria/20110606_eldorado.html.

49 Lazzarini, Capitalismo de laços, p 106.

50 Sinticel-es, Suport-es, Rede Alerta, Famopes, mndh-es, fase, mst, cut-es, Intersindical da Orla Portuária, Sintrexbem, Sintec-es, Sindimetal-es, Sindilimpe-es, Sintracical-es, Sindiupes \& Oposição Sintramassas, A face desumana da Aracruz Celulose (Fibria) contra seus trabalhadores, 15 March 2010, at http://www.adital.com.br/ site/ noticia. asp?lang=PT\&cod=46176.

51 lbid.

52 Bacchetta, 'La industria de la celulosa y la crisis mundial'.

53 Aracruz Celulose, 'M aterial information release'.

54 Bacchetta, 'La industria de la celulosa y la crisis mundial'.

55 Sinticel-es et al, A face desumana da Aracruz Celulose (Fibria) contra seus trabalhadores.

56 Interview with Frei Antonio, M issionario Comboniano and founder of Justiça nos Trilhos, Açailandia, Maranhão, 17 March 2011.

57 bndes, 'O fat e o bndes', 2011, at http://www.bndes.gov.br/SiteBNDES/bndes/bndes_pt/Institucion al/BNDES Transparente/Fundos/Fat/fat_bndes.html.

58 R Boschi \& F Gaitán, 'Politics and development: lessons from Latin America', Brazilian Political Science Review, 3(2), 2009, pp 11-29.

59 R Almeida, 'Entrando no clube', pp 177-180.

60 A Ferrer, 'Desarrollo comparado: Argentina, Brasil y Chile', La Mañana (Buenos Aires), 28 September 2010.

61 R de Almeira, 'Eike Batista, o brasileiro que quer ser o mais rico do mundo', iG Economia, 2011, at http://economia.ig.com.br/ eike+batista to +brasileiro +que+quer +ser to +maistrico+do+mundo/n1 237561676494.html.

62 Lazzarini, Capitalismo de laços, p 3. 
63 Berterretche, 'Brasil petista'; and Santana, 'Conjuntura crítica, legados institucionais e comunidades epistêmicas'.

64 L Casanova, 'Del "consenso de Washington" al "consenso brasileño": el nuevo poder empresarial brasileño', América Economía, April 2010.

65 Bacchetta, 'La industria de la celulosa y la crisis mundial'.

66 Lazzarini, Capitalismo de laços.

67 Casanova, 'Del "consenso de Washington" al "consenso brasileño"'.

68 Berterretche, 'Brasil petista'.

69 Santana, 'Conjuntura crítica, legados institucionais e comunidades epistêmicas', p 147.

70 S Fontes, 'Pesos pesados retornam ao setor florestal', Valor Econômico, 28 M ay 2011.

71 See M Kröger \& J-E Nylund, 'The conflict over Veracel pulpwood plantations in Brazil-application of ethical analysis', Forest Policy and Economics, 14, 2012, pp 74-82.

72 S Scheibe, 'The history of Brazilian pulp and paper: a contextual approach looking to the future', power point presentation at the 43rd Pulp and Paper International Congress \& Exhibition, 2010, at http://www.abtcp.org.br/arquivos/File/ABTCP\%202010/Congresso/05\%20de\%20outubro/A\%20hist \%C3\%B3ria\%20do\%20papel\%20e\%20celulose_Stephen\%20Scheibe_All\%20Abroad.pdf.

73 C Santana, 'Conjuntura crítica, legados institucionais e comunidades epistêmicas', p 136.

74 See K Hochstetler \& M Keck, Greening Brazil: Environmental Activism in State and Society, London: Duke University Press, 2007; P Kingstone \& A Ponce, 'From Cardoso to Lula: the triumph of pragmatism in Brazil', in K Weyland, R M adrid \& W Hunter (eds), Leftist Governments in Latin America: Successes and Shortcomings, Cambridge: Cambridge University Press, 2010; and W Wolford, 'Participatory democracy by default: land reform, social movements and the state in Brazil', Journal of Peasant Studies, 37, 2010, pp 91-109.

75 Gills, 'Going South'.

76 Lazzarini, Capitalismo de laços, p 13.

77 Ibid, p 112. 